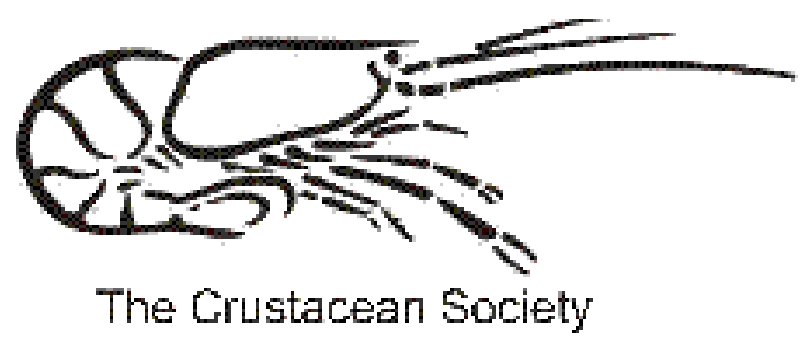

\author{
Enhancement of Microbicidal Activity in the Tiger Shrimp Penaeus monodon via \\ Immunostimulation \\ Author(s): H. H. Sung, Y. L. Yang, Y. L. Song \\ Source: Journal of Crustacean Biology, Vol. 16, No. 2 (May, 1996), pp. 278-284 \\ Published by: The Crustacean Society \\ Stable URL: http://www.jstor.org/stable/1548883 \\ Accessed: 06/05/2009 02:59
}

Your use of the JSTOR archive indicates your acceptance of JSTOR's Terms and Conditions of Use, available at http://www.jstor.org/page/info/about/policies/terms.jsp. JSTOR's Terms and Conditions of Use provides, in part, that unless you have obtained prior permission, you may not download an entire issue of a journal or multiple copies of articles, and you may use content in the JSTOR archive only for your personal, non-commercial use.

Please contact the publisher regarding any further use of this work. Publisher contact information may be obtained at http://www.jstor.org/action/showPublisher?publisherCode=crustsoc.

Each copy of any part of a JSTOR transmission must contain the same copyright notice that appears on the screen or printed page of such transmission.

JSTOR is a not-for-profit organization founded in 1995 to build trusted digital archives for scholarship. We work with the scholarly community to preserve their work and the materials they rely upon, and to build a common research platform that promotes the discovery and use of these resources. For more information about JSTOR, please contact support@jstor.org.

The Crustacean Society is collaborating with JSTOR to digitize, preserve and extend access to Journal of Crustacean Biology. 


\title{
ENHANCEMENT OF MICROBICIDAL ACTIVITY IN THE TIGER SHRIMP PENAEUS MONODON VIA IMMUNOSTIMULATION
}

\author{
H. H. Sung, Y. L. Yang, and Y. L. Song
}

\begin{abstract}
A B S T R A C T
We studied the clearance ability of hemolymph drawn from the tiger shrimp Penaeus monodon immersed in a viable cell suspension of Vibrio vulnificus. Results show that Vibrio cells were largely eliminated from shrimp hemolymph within $12 \mathrm{~h}$ following invasion and completely undetectable at $24 \mathrm{~h}$. We also examined the anti-E. coli activity of plasma, phenoloxidase (PO) activity, as well as the production of superoxide anion $\left(\mathrm{O}_{2}^{-}\right)$by shrimp hemocytes following treatment with each of these 3 immunostimulants. Resultant survival indexes show that some plasma, but not all, exhibits anti-E. coli activity. However, such an activity in all plasma tested could be enhanced by beta-glucan or zymosan up to $24 \mathrm{~h}$ following treatment, and slightly enhanced at $6 \mathrm{~h}$ following treatment with a Vibrio antigen. $\mathrm{PO}$ activity and $\mathrm{O}_{2}{ }^{-}$generation were stimulated by all 3 immunostimulants. Enhanced PO activities were observed from 5 min to $24 \mathrm{~h}$ following treatment, with the highest activity occurring at $3 \mathrm{~h}$; the activity recovered to normal on day 3. Increased $\mathrm{O}_{2}{ }^{-}$production was observed from 3-12 $\mathrm{h}$ in both glucan- and zymosan-treated shrimp, and at $6 \mathrm{~h}$ in shrimp treated with Vibrio antigen. These results show that: (1) some microbicidal reactions may be involved in the clearance of invasive $V$. vulnificus from shrimp hemolymph; (2) the 3 immunostimulants have the ability to enter shrimp via immersion treatment, thus leading to activation of both the plasma-related factors and hemocytes and the strengthening of $\mathrm{PO}$ activity and $\mathrm{O}_{2}{ }^{-}$production; and (3) these enhanced microbicidal reactions exhibit a rapid response that is short in duration.
\end{abstract}

Decapod crustaceans have the capability of rapidly clearing invading bacteria from their hemolymph (Cornick and Stewart, 1968; McKay et al., 1969; McKay and Jenkin, 1970; Smith and Ratcliffe, 1980; White and Ratcliffe, 1982; McCumber and Clem, 1983; Adams, 1991; Martin et al., 1993). Examples have been reported of lobsters, shore crabs, and penaeid shrimps removing in excess of $75 \%$ of bacterial cells within $10 \mathrm{~min}$ to $1 \mathrm{~h}$ after injection (Cornick and Stewart, 1968; White and Ratcliffe, 1982; Adams, 1991; Martin et al., 1993). Both humoral and cellular responses are thought to be involved in this clearance reaction. Crustaceans possess a wide variety of noncellular factors that are both naturally occurring, inducible, bioactive molecules (e.g., agglutinin, killing factors, lysins, precipitins, and clotting agents) (Smith and Chisholm, 1992). Some antibacterial factors have been found in lobster plasma, such as bactericidins, which were perceived as being effective against a variety of bacteria in lobsters (Cornick and Stewart, 1968; Stewart and Zwicker, 1972; Mori and Stewart, 1978).

The circulating hemocytes plus tissue phagocytes, which are primarily found in crustacean gills, have been implicated in the clearance of invading microorganisms (Smith and Ratcliffe, 1980). These cells remove foreign particles in the crustacean hemocoel by phagocytosis (McKay and Jenkin, 1970; Fontaine and Lightner, 1974; Paterson and Stewart, 1974; Paterson et al., 1976; Smith and Ratcliffe, 1978, 1980; Goldenberg et al., 1984), or hemocyte encapsulation which is initiated by the prophenoloxidase activating system (Unestam and Söderhäll, 1977; Söderhäll, 1982; Smith and Söderhäll, 1983; Hose et al., 1990).

Many crustacean researchers have documented that the prophenoloxidase (proPO) activating system functions in nonself recognition and host defense (Söderhäll, 1982; Ratcliffe et al., 1985; Smith and Söderhäll, 1991). More importantly, proteins that are associated with the proPO system have been shown to be directly involved in the communication between hemocytes and also in the elimination of foreign particles, such as parasites, within the body cavity of crayfish (Söderhäll et al., 1994). In addition, some microbial products, such as beta- 
1,3-glucan from fungal cell walls, and lipopolysaccharide and peptidoglycan from bacterial cell walls have been recognized as elicitors of the proPO system (Unestam and Söderhäll, 1977; Söderhäll and Unestam, 1979; Yoshida and Ashida, 1986; Söderhäll et al., 1990). Our previous study also showed that the proPO activating system of shrimp hemocytes could be enhanced by in vitro beta-glucan treatment (Sung et al., 1994). In addition, Song and Hsieh (1994) demonstrated in vitro a respiratory burst in shrimp hemocytes which was thought to be related to phagocytosis.

The aim of the present research was to investigate the relative microbicidal reactions associated with the clearance of bacteria, as well as to evaluate the stimulative effects of three immunostimulants applied to shrimp in vivo.

\section{Materials AND Methods}

Experimental Animals.-Tiger shrimp (Penaeus monodon Fabricius), each weighing 30-40 g, were purchased from a local market and acclimated to $2.5 \%$ salinity $/ 25^{\circ} \mathrm{C}$ pond water in a $120-1$ plastic container for 2 days prior to our experiments. The stocking density was 4 individuals per 1 .

Preparation of Bacterial Suspension.-The TG617 strain of Vibrio vulnificus (see Song et al., 1990) used for the clearance test was cultured overnight in tryptic soy broth (TSB containing $3 \% \mathrm{NaCl}$ ) at $28^{\circ} \mathrm{C}$. Before immersion treatment, the concentration of bacterial suspension was adjusted to $10^{7} \mathrm{CFU}$ (colony forming unit) per ml of pond water. In addition, the V517 strain of Escherichia coli (see Macaina et al., 1978) was cultured overnight in TSB (tryptic soy broth, Difco) at $37^{\circ} \mathrm{C}$, after which it was subcultured in $10 \mathrm{ml}$ of TSB. After concurrent shaking and incubation for $2 \mathrm{~h}$ at $37^{\circ} \mathrm{C}$, the resultant $\log$-phase suspension was serially diluted in sterile $0.85 \% \mathrm{NaCl}$ solution to a concentration of $5 \times 10^{3} \mathrm{CFU}$ per $\mathrm{ml}$ for use in the bactericidal assay.

Immunostimulants. - Three immunostimulants used for our experiments were: (a) Vibrio antigen (heat-killed cells of Vibrio vulnificus), previously shown to induce shrimp vibriosis resistance (Sung et al., 1991); (b) beta-1,3-1,6-glucan extracted from Saccharomyces cerevisiae (Biotec Mackzymal, Tromsö), known to strengthen shrimp resistance against vibriosis (Sung $e t$ al., 1994); and (c) zymosan, a beta-1,3-glucan-proteinlipid compound extracted from the cell walls of $S$. cerevisiae (Sigma), known to enhance nonspecific defenses in certain organisms via activation of the properdin system. Prior to immersion treatment, the betaglucan and zymosan were prepared at concentrations of $1.0 \mathrm{mg}$ per $\mathrm{ml}$ of pond water ( $2.5 \%$ salinity), and the concentration of the heat-killed Vibrio cell suspension was adjusted to $1 \times 10^{7} \mathrm{cells} / \mathrm{ml}$.

Bacterial Clearance.-In order to determine whether or not bacteria were cleared from hemolymph, our ex- perimental shrimp were immersed in a viable cell suspension of $V$. vulnificus $\left(10^{7} \mathrm{CFU} / \mathrm{ml}\right)$ for $3 \mathrm{~h} ; 0.5 \mathrm{ml}$ of hemolymph was drawn from each shrimp ( 5 individuals per test) at $5 \mathrm{~min}$ and $3,6,12$, and $24 \mathrm{~h}$ postimmersion. One hundred $\mu \mathrm{l}$ of hemolymph diluted with sterile saline was spread onto triplicate TCBS (thiosulfate citrate bile sucrose, Difco) agar plates, which were then incubated overnight at $28^{\circ} \mathrm{C}$. The numbers of bacterial colonies per plate were counted and calculated to determine the number of CFU per $\mathrm{ml}$ of hemolymph.

Immersion Treatment.-Three groups of tiger shrimps were separately immersed for $3 \mathrm{~h}$ in the suspension of beta-glucan, zymosan, and Vibrio antigen at a density of 4 individuals per 1; control shrimp were immersed in immunostimulant-free pond water. Following treatment, the shrimps were kept in aerated pond water and 15 individuals were chosen at random at $5 \mathrm{~min}$ and 3 , $6,12,24$, and $72 \mathrm{~h}$ for hemolymph extraction.

Anti-E. coli Activity Assay.-Antibacterial activity in plasma was determined by plate count method. Approximately $15 \mathrm{ml}$ of hemolymph from 15-20 shrimps were drawn into anticoagulant $(0.01 \mathrm{M}$ Tris- $\mathrm{HCl}, 0.25$ M sucrose, $0.1 \mathrm{M}$ trisodium citrate; $\mathrm{pH}$ 7.6) treated tubes, pooled, and centrifuged at $300 \mathrm{~g}$ for $10 \mathrm{~min}$ at $4^{\circ} \mathrm{C}$ to remove hemocytes, which were then used for the phenoloxidase activity assay. Plasma derived from the immunostimulant-treated groups or control group was concentrated by a factor of 3 via centrifugation through a centricon (Amico, Centriprep 3) at 3,000 g for $3 \mathrm{~h}$; they were then sterilized by filtration (Sartorius filter membrane, $0.45 \mu \mathrm{m}$ pore size). The resultant mixed suspension of $4.5 \mathrm{ml}$ concentrated plasma plus $0.5 \mathrm{ml}$ cell suspension of $E$. coli $\left(5 \times 10^{3} \mathrm{CFU} / \mathrm{ml}\right)$ was reacted by shaking gently at $37^{\circ} \mathrm{C}$ for $60 \mathrm{~min}$. One hundred $\mu \mathrm{l}$ of this mixture was adequately diluted and then spread onto triplicate tryptic soy agar plates, and cells of $E$. coli were allowed to grow overnight at $37^{\circ} \mathrm{C}$ before colony counting. The survival index (SI) of $E$. coli (modified from Wardlaw and Unkles, 1978) was calculated as follows:

$$
\mathrm{SI}=\frac{\begin{array}{c}
\text { CFUs per ml of mixture } \\
\text { survived after } 60 \text {-min reaction }
\end{array}}{\begin{array}{c}
\text { CFUs per } \mathrm{ml} \text { of mixture } \\
\text { survived at time } 0 \text { of reaction }
\end{array}}
$$

Anti-E. coli activity was expressed as the ratio of the survival index for the immunostimulated shrimps to that of the control group; enhancement occurred if the ratio was less than 1 .

Hemocyte Lysate Supernatant Preparation.-Shrimp hemocyte lysate supernatant (HLS) was prepared for each group as described by Smith and Söderhäll (1991). Briefly, hemocytes were washed with cacodylate-citrate buffer $(0.01 \mathrm{M}$ sodium cacodylate, $0.45 \mathrm{M}$ $\mathrm{NaCl}, 0.1 \mathrm{M}$ trisodium citrate; $\mathrm{pH} 7.0$ ) by centrifugation at $300 \mathrm{~g}$ for $10 \mathrm{~min}$. Following removal of the supernatant, hemocyte pellets were resuspended in chilled 1:10 cacodylate (CAC) buffer $(0.01 \mathrm{M}$ sodium cacodylate, $0.45 \mathrm{M} \mathrm{NaCl}, 10 \mathrm{mM} \mathrm{CaCl}, 26 \mathrm{mM}$ $\mathrm{MgCl}_{2} ; \mathrm{pH}$ 7.0). This suspension was homogenized with a sonicator (Vibra cell, AC-600) equipped with a microtip (output 5 , duty cycle $50 \%$ ), and centrifuged at $43,000 \mathrm{~g}$ for $20 \mathrm{~min}$ at $4^{\circ} \mathrm{C}$. The resultant HLS was used as an enzyme source and kept at $-20^{\circ} \mathrm{C}$ before assaying for phenoloxidase (PO) activity. HLS protein 
Table 1. Clearance of viable cells of Vibrio vulnificus from hemolymph of tiger shrimp (Penaeus monodon).

\begin{tabular}{cc}
\hline $\begin{array}{c}\text { After } \\
\text { immersion }\end{array}$ & $\begin{array}{c}\text { V. vulnificus } \\
\text { CFU/ml }(N=5)\end{array}$ \\
\hline $5 \mathrm{~min}$ & $(1.2+0.1) \times 10^{6}$ \\
$3 \mathrm{~h}$ & $(7.5+0.5) \times 10^{4}$ \\
$6 \mathrm{~h}$ & $(1.8+0.4) \times 10^{2}$ \\
$12 \mathrm{~h}$ & trace \\
$24 \mathrm{~h}$ & 0 \\
\hline
\end{tabular}

$\mathrm{CFU}=$ Colony forming unit.

$N=$ Number of shrimp from which hemolymph was drawn.

concentration was determined via the Bradford method, using bovine serum albumin (BioRad Protein Assay Kit II) as a standard.

Phenoloxidase Activity Assay.-PO activity was estimated with a spectrophotometer set at $490 \mathrm{~nm}$, using L-dihydroxyphenylalanine (L-dopa, Sigma) as a substrate. We kept $200 \mu \mathrm{l}$ of each sample at $37^{\circ} \mathrm{C}$ for 15 $\mathrm{min}$, after which $400 \mu \mathrm{l}$ of L-dopa $(1.6 \mathrm{mg} / \mathrm{ml}$ in CAC buffer) was added and reacted for $1 \mathrm{~min}$. Each reaction mixture was further diluted with $400 \mu$ l of CAC buffer. We then measured the absorbance of optic density at a wave length of $490 \mathrm{~nm}$. One unit of enzyme activity is defined as an increase in absorbance of $0.001 / \mathrm{min} /$ mg protein (Söderhäll and Unestam, 1979). We used the ratio of enzyme activity of the stimulated shrimp to that of control shrimp as an index for comparing the effects of different immunostimulants on PO activity.

Intracellular Superoxide Anion $\left(\mathrm{O}_{2}^{-}\right)$Assay.-This assay was conducted as described by Song and Hsieh (1994). Reactions occurred in flat-bottomed 96-well microtiter plates, with each well being coated with 100 $\mu l$ poly-L-lysine solution $(0.2 \%$, Sigma) to increase the number of adhesive hemocytes (Miosky et al., 1989). Approximately $1.0 \mathrm{ml}$ of shrimp hemolymph was collected from a single shrimp with a 26-gauge hypodermic needle on a 2-ml syringe containing $0.4 \mathrm{ml}$ of anticoagulant. The collected hemolymph was centrifuged at $300 \mathrm{~g}$ for $10 \mathrm{~min}$ at $4^{\circ} \mathrm{C}$; the resultant hemocyte pellet was then resuspended to $10^{7}$ cells $/ \mathrm{ml}$ in a modified complete Hank's balanced salt solution (MCHBSS containing $10 \mathrm{mM} \mathrm{CaCl}, 3 \mathrm{mM} \mathrm{MgCl}, 5$ $\mathrm{mM} \mathrm{MgSO}, 24 \mathrm{mg} / \mathrm{ml} \mathrm{HBSS}$ (Sigma)). One hundred $\mu l$ of hemocyte suspension was added to each well $\left(10^{6}\right.$ hemocytes/well) and cytocentrifuged (Kubota, KN-70) at $300 \mathrm{~g}$ for $10 \mathrm{~min}$ at $4^{\circ} \mathrm{C}$. After removing the supernatant, $100 \mu \mathrm{l}$ of MCHBSS was added and the hemocytes were stained with $100 \mu l$ nitroblue tetrazolium solution (NBT, $0.3 \%$ in MCHBSS) for $30 \mathrm{~min}$ at $37^{\circ} \mathrm{C}$. The staining reaction was terminated by removing the NBT solution and adding absolute methanol. After 3 washings with $70 \%$ methanol, the hemocytes were air-dried and coated with a solution of $120 \mu \mathrm{l}$ $\mathrm{KOH}(2 \mathrm{M})$ and $140 \mu \mathrm{l}$ DMSO (dimethyl sulfoxide) to dissolve the cytoplasmic formazan; the optical densities of the dissolved cytoplasmic formazan were measured at $630 \mathrm{~nm}$ with a Precision microplate reader (Emax) (Leslie, 1987; Leslie and Allen, 1987). In order to determine the reproducibility of our results, hemocytes collected from 5 shrimps were individually assayed. We used the ratio of $\mathrm{OD}_{630}$ from the hemocytes of treated shrimp to the $\mathrm{OD}_{630}$ of the hemocytes
Table 2. Anti-E. coli activity in plasma derived from tiger shrimp (Penaeus monodon) treated with immunostimulants via immersion.

\begin{tabular}{cccc}
\hline \hline \multirow{3}{*}{$\begin{array}{c}\text { After } \\
\text { immersion }\end{array}$} & $\begin{array}{c}\text { Vibrio } \text { antigen } \\
\left(10^{7} \text { cells/ml }\right)\end{array}$ & $\begin{array}{c}\text { Zymosan } \\
(1 \mathrm{mg} / \mathrm{ml})\end{array}$ & $\begin{array}{c}\text { Beta-glucan } \\
(1 \mathrm{mg} / \mathrm{ml})\end{array}$ \\
\hline Control & $0.67(1.00)^{\mathrm{b}}$ & $1.42(1.00)$ & $1.28(1.00)$ \\
$3 \mathrm{~h}$ & $0.73(1.08)$ & $0.55(0.39)$ & $0.72(0.56)$ \\
$6 \mathrm{~h}$ & $0.55(0.81)$ & $0.75(0.53)$ & $0.58(0.45)$ \\
$12 \mathrm{~h}$ & $0.63(0.94)$ & $1.06(0.75)$ & $0.77(0.60)$ \\
$24 \mathrm{~h}$ & $0.80(1.19)$ & $1.28(0.90)$ & $0.68(0.53)$ \\
\hline
\end{tabular}

${ }^{a}$ Survival index $(\mathrm{SI})=\mathrm{CFU}$ after $60 \mathrm{~min}$ reaction/CFU at time 0 of reaction.

${ }^{b}$ Ratio of SI $=$ SI of shrimp treated with immunostimulant/SI of control group.

of control shrimp as an index for comparing the effects of different immunostimulants on $\mathrm{O}_{2}{ }^{-}$generation.

\section{RESULTS}

\section{Clearance of Viable Bacteria from Plasma}

To study the clearance of Vibrio cells from the hemolymph of our experimental tiger shrimps, we calculated the number of viable cells of $V$. vulnificus present at 5 $\min , 3,6,12$, and $24 \mathrm{~h}$ following waterborne infection using a plate count method. It showed that about $10 \%$ of bacteria could invade hemolymph when assayed at $5 \mathrm{~min}$. The number of viable Vibrio cells decreased substantially in a short period of time; the total Vibrio cell count fell by two logs within $3 \mathrm{~h}$ and four logs within $6 \mathrm{~h}$ following infection. A very small number of viable Vibrio cells were detected at 12 h, but were completely undetectable at 24 h (Table 1).

\section{Anti-E. coli Activity of Plasma}

In order to determine whether or not shrimp-clearance reaction is undertaken either via the plasma or the hemocytes, we examined the antibacterial activity of plas$\mathrm{ma}$, as well as intrahemocytic PO activity and $\mathrm{O}_{2}^{-}$generation of shrimp in the three treatment groups. As shown in Table 2, the survival index ratio of $E$. coli was less than 1 from 3-24 h following treatment with glucan or zymosan, but less than 1 only at 6 and $12 \mathrm{~h}$ in shrimps treated with Vibrio antigen. In addition, the SI of $E$. coli in the control group was greater than 1 in both experiments that were treated by zymosan and glucan, respectively. The result showed that the two control plasma groups did not 
Table 3. Intrahemocytic phenoloxidase activity in tiger shrimp (Penaeus monodon) treated with immunostimulants via immersion.

\begin{tabular}{ccrc}
\hline \hline \multirow{2}{*}{$\begin{array}{c}\text { After } \\
\text { immersion }\end{array}$} & \multicolumn{3}{c}{ Phenoloxidase activity (U/mg/min) } \\
\cline { 2 - 4 } & $\begin{array}{c}\text { Vibrio antigen } \\
\left(10^{7} \text { cells/ml }\right)\end{array}$ & \multicolumn{1}{c}{$\begin{array}{c}\text { Zymosan } \\
(1 \mathrm{mg} / \mathrm{ml})\end{array}$} & $\begin{array}{c}\text { Beta-glucan } \\
(1 \mathrm{mg} / \mathrm{ml})\end{array}$ \\
\hline Control & $5.04(1.0)^{\mathrm{a}}$ & $2.30(1.0)$ & $1.65(1.0)$ \\
$5 \mathrm{~min}$ & $7.92(1.6)$ & $4.80(2.1)$ & $2.29(1.4)$ \\
$3 \mathrm{~h}$ & $13.14(2.6)$ & $16.60(7.2)$ & $7.29(4.4)$ \\
$6 \mathrm{~h}$ & $7.56(1.5)$ & $13.85(6.0)$ & $6.60(4.0)$ \\
$12 \mathrm{~h}$ & $8.99(1.8)$ & $12.00(5.2)$ & $3.93(2.4)$ \\
$24 \mathrm{~h}$ & $8.86(1.8)$ & $7.14(3.1)$ & $2.86(1.7)$ \\
$72 \mathrm{~h}$ & $4.91(1.0)$ & $2.43(1.1)$ & $1.57(1.0)$
\end{tabular}

a Ratio of PO activity = PO activity in shrimp treated with immunostimulant/PO activity in control group.

exhibit anti-E. coli activity before stimulation.

\section{Intracellular PO Activity}

A quantitative analysis of the stimulative effects of each of the three immunostimulants on intrahemocytic PO activity in shrimp showed that $\mathrm{PO}$ activities from 5 min to 1 day following immersion were all greater than those observed in control shrimp; however, on day 3 the separate PO activities of the three treated shrimp dropped to those observed in control groups (Table 3). Our data on the ratio of PO activity in immunostimulated shrimp to that in control shrimp showed that intrahemocytic PO activity was increased by immunostimulant treatment immediately following immersion, with the greatest activity occurring at $3 \mathrm{~h}$; in addition, we found that this activity lasted until day 3 .

\section{Intrahemocytic $\mathrm{O}_{2}{ }^{-}$Production}

We also used NBT-staining to measure the generation of $\mathrm{O}_{2}^{-}$by hemocytes for each of the three treatment groups. We found that $\mathrm{O}_{2}^{-}$production was significantly greater in glucan- and zymosan-treated shrimp compared to control shrimp from 3$6 \mathrm{~h}$ following immersion. However, $\mathrm{O}_{2}{ }^{-}$ production was greater in Vibrio antigentreated shrimp only at $6 \mathrm{~h}$ (Table 4). In addition, the strongest level of $\mathrm{O}_{2}^{-}$production was detected at $3 \mathrm{~h}$ in glucan-treated shrimp, and at $6 \mathrm{~h}$ in both Vibrio antigenand zymosan-treated shrimp.

\section{DisCUSSION}

Our results show that about $10 \%$ of the viable bacteria could invade the hemo-
Table 4. Intrahemocytic $\mathrm{O}_{2}^{-}$production in tiger shrimp treated with immunostimulants.

\begin{tabular}{|c|c|c|c|}
\hline \multirow[b]{2}{*}{$\begin{array}{c}\text { After } \\
\text { immersion }\end{array}$} & \multicolumn{3}{|c|}{ Production of $\mathrm{O}_{2}^{-}\left(\mathrm{OD}_{630}\right)(N=5)$} \\
\hline & $\begin{array}{l}\text { Vibrio antigen } \\
\left(10^{7} \text { cells } / \mathrm{ml}\right)\end{array}$ & $\begin{array}{c}\text { Zymosan } \\
(1 \mathrm{mg} / \mathrm{ml})\end{array}$ & $\begin{array}{l}\text { Beta-glucan } \\
(1 \mathrm{mg} / \mathrm{ml})\end{array}$ \\
\hline Control & $0.123(1.00)^{\mathrm{a}}$ & $0.114(1.00)$ & $0.165(1.00)$ \\
\hline $5 \mathrm{~min}$ & $0.094(0.76)$ & $0.116(1.02)$ & $0.173(1.05)$ \\
\hline $3 \mathrm{~h}$ & $0.125(1.02)$ & $0.210(1.84)^{*}$ & $0.312(1.89)^{*}$ \\
\hline $6 \mathrm{~h}$ & $0.225(1.83)^{*}$ & $0.323(2.83)^{*}$ & $0.272(1.65)^{*}$ \\
\hline $12 \mathrm{~h}$ & $0.103(0.84)$ & $0.177(1.55)$ & $0.193(1.17)$ \\
\hline $24 \mathrm{~h}$ & $0.090(0.73)$ & $0.119(1.04)$ & $0.162(0.98)$ \\
\hline
\end{tabular}

lymph through the immersion route. However, tiger shrimp can clear invading bacteria from their hemolymph. About $94 \%$ of cells of $V$. vulniticus were cleared within 3 $\mathrm{h}$, and the escaping bacteria were almost completely cleared within the next $3 \mathrm{~h}$. Viable bacterial cells were undetectable at 24 h following water-borne infection. Adams (1991) reported that more than $99 \%$ of heatkilled Vibrio alginolyticus were cleared from hemolymph of Penaeus monodon within $4 \mathrm{~h}$ after exposure. The difference between the experiments of Adams and our experiments might be that the clearance of viable pathogenic bacteria from hemolymph in our experiments was not as efficient as the clearance of heat-killing bacteria in the experiments of Adams. Moreover, bacteria used by Adams were completely undetectable 2-5 days following injection treatment. This delayed clearance is probably due to the fact that Adams used an EIA (enzyme immunoassay) which detected both intact bacteria and also debris resulting from either phagocytosis or digestion by lysozyme. Conclusively, clearance of foreign materials from shrimp hemolymph occurred rapidly within $6 \mathrm{~h}$. Any strategy enhancing the clearance activities with an onset greater than $4 \mathrm{~h}$ would have a limited bactericidal effect.

Substances that have attracted the most research interest, especially in shore crabs, Carcinus maenas (L.), and lobsters, are bactericidins (Cornick and Stewart, 1968, 1975). However, they were not found in the plasma (Smith and Ratcliffe, 1978), but were found in the hemocytes (Chisholm and Smith, 1991). To the contrary, our re- 
search showed that antibacterial activity is detectable in tiger shrimp plasma concentrated by a factor of three. Such a quick antibacterial response can be enhanced by stimulation of shrimp with the three tested immunostimulants, but it was a short-lived response. Therefore, we conjecture that antibacterial substances found in shrimp plasma may be inducibly released from hemocytes by immersing shrimp in immunostimulants. Our data also show that not all control plasma has anti-E. coli activity before stimulation. The possible explanation of this variation is the variability of the growth of shrimp reared together under conditions typical of shrimp ponds in Taiwan. The phenomena also occurred in PO activity (Sung et al., 1994). Further research is required to understand the details of immunostimulation.

Phenoloxidase can be activated in crustaceans in vitro by LPS (lipopolysaccharide), and it serves functions in nonself recognition and host defense (Smith and Söderhäll, 1991); which include, as well, bactericidal activity and phagocytosis (Unestam and Söderhäll, 1977). Sung et al. (1994) have similarly reported the presence of PO in shrimp hemocytes. This enzymatic activity can be enhanced in vitro by beta-glucan treatment, which may contribute to the enhancement of disease resistance in tiger shrimp. In the present study, we confirmed that $\mathrm{PO}$ activity was stimulated in vivo by each of the three tested immunostimulants, and was seemingly increased before either antibacterial activity or $\mathrm{O}_{2}^{-}$production. Smith and Söderhäll (1983) reported that beta- 1,3 glucans can activate the proPO activating system, and initiate a cellular defense reaction, such as degranulation. Therefore, we suspect that the proPO system in shrimp is probably similar to that in other crustaceans, and may play a role in both nonself recognition and help initiate antibacterial activity and phagocytosis.

We also found that PO activity levels varied considerably according to stimulant type; the stimulative effects of beta-glucan and zymosan were stronger than that of the Vibrio antigen. Söderhäll and Hall (1984) reported that the proPO system in crayfish was triggered by such microbial products as LPS and beta-1,3-glucan, but through different activating pathways. Many studies showed that the activation of proPO system exerted by beta-1,3-glucan is specific via a beta-1,3-glucan binding protein ( $\beta G B P$ ), which is found in the plasma of both insects and several crustaceans (Söderhäll et al., 1994). However, in crustaceans, no specific factors have been found to bind to LPS until now. Hence, we suggest that the stimulative mechanism(s) in the proPO activating system of shrimp may differ according to the immunostimulant used, and that a $\beta G B P-l i k e$ substance may be present in shrimp plasma.

Stimulated phagocytes are known to produce highly reactive oxygen species with powerful microbicidal activity. The earliest product among highly reactive oxygen species is $\mathrm{O}_{2}^{-}$. Song and Hsieh (1994) reported that $\mathrm{O}_{2}^{-}$and $\mathrm{H}_{2} \mathrm{O}_{2}$ play more important roles in microbicidal activity than do $\mathrm{OCl}^{-}$ (hypochlorite) and MPO (myeloperoxidase) activity in tiger shrimp. Connors and Yoshino (1990) reported that hemocytes from Biomphalaria glabrata (Say) resistant to Schistosoma mansoni Sambon possess a greater capacity for generating superoxide anion than those taken from susceptible snails. Our results show that $\mathrm{O}_{2}^{-}$production could be enhanced by treatment with the three immunostimulants. The greatest production of $\mathrm{O}_{2}^{-}$occurred from 3-6 h poststimulation, and the stimulative effect lasted for no more than $24 \mathrm{~h}$. Based on these results, we conclude that: (1) the phagocytotic hemocytes of shrimp could be activated to produce $\mathrm{O}_{2}^{-}$and probably initiate the cascade of highly reactive oxygen species, all of which have the ability to kill invading microorganisms; (2) because of its rapid reaction rate, $\mathrm{O}_{2}^{-}$was very important for acute responses; and (3) because $\mathrm{O}_{2}^{-}$works nonspecifically and is thus capable of attacking host cells as well as microorganisms, a short-term response is required to confine the reaction to designated targets. Hence, work needs to be done on adequately maintaining the stimulative effects of immunostimulants for longer durations to enhance disease resistance in shrimp.

\section{ACKNOWLEDGEMENTS}

This research was supported by the Council of Agriculture, Republic of China (grant no. COA-83-BT$1.1-\mathrm{F}-61(66-3)$ to YLS). 


\section{LITERATURE CITED}

Adams, A. 1991. Response of penaeid shrimp to exposure to Vibrio species.-Fish and Shellfish Immunology 1: 59-70.

Chisholm, J. R. S., and V. J. Smith. 1991. Antibacterial activity in Carcinus maenas hemocytes. Journal of the Marine Biological Assuciation of the United Kingdom 72: 529-542.

Connors, V. A., and T. P. Yoshino. 1990. In vitro effect of larval Schistosoma mansoni excretory-secretory products on phagocytosis-stimulated superoxide production in hemocytes from Biomphalaria glabrata.-Journal of Parasitology 76: 895-902.

Cornick, J. W., and J. E. Stewart. 1968. Interaction of the pathogen Gaffkya homari with natural agglutinin.- Journal of the Fisheries Research Board of Canada 25: 695-709.

, and - 1975. Red crab (Geryon quin quedens) and snow crab (Chionoecetes opilio) resistance to infection by the lobster pathogen Aerococcus viridans (var.) homari.-Journal of the Fisheries Research Board of Canada 32: 702-706.

Fontaine, C. T., and D. V. Lightner. 1974. Observations on the phagocytosis and elimination of carmine particles injected into the abdominal musculature of the white shrimp, Penaeus setiferus.-Journal of Invertebrate Pathology 24: 141-148.

Goldenberg, P. Z., E. Huebner, and A. H. Greenberg. 1984. Activation of lobster hemocytes for phagocytosis.-Journal of Invertebrate Pathology 43: 7788.

Hose, J. E., G. G. Martin, and A. S. Gerard. 1990. A decapod hemocyte classification scheme integrating morphology, cytochemistry and function.-Biological Bulletin 178: 33-45.

Leslie, R. G. Q. 1987. Evaluation and improvement of a rapid microassay for measuring superoxide anion production by phagocytes. 1. Spectrophotometric aspects.- Journal of Immunological Methods 103: 253-259.

, and R. Allen. 1987. Evaluation and improvement of a rapid microassay for measuring superoxide anion production by phagocytes. 2 . Biochemical aspects.-Journal of Immunological Methods 103: 261-266.

$\rightarrow$ Macrina, F. L., D. J. Kopecko, K. R. Jones, D. J. Ayers, and S. M. McCowen. 1978. A multiple plasmidcontaining Escherichia coli strain: convenient source of size reference plasmid molecules.-Plasmid 1: 417-420.

McCumber, L. J., and L. W. Clem. 1983. Recognition of non-self in crustaceans.-American Zoologist 23: 173-183.

McKay, D., and C. R. Jenkin. 1970. Immunity in the invertebrates. The role of serum factors in phagocytosis of erythrocytes by hemocytes of the freshwater crayfish (Parachaeraps bicarinatus).--Australian Journal of Experimental Biology and Medical Science 48: 139-150.

, and D. Rowley. 1969. Immunity in the invertebrates. I. Studies on the naturally occurring haemagglutinins in the fluid from invertebrates.-Australian Journal of Experimental Biology and Medical Science 47: 125-134.

Martin, G. G., D. Poole, C. Poole, J. E. Hose, M. Arias, L. Reynolds, N. McKrell, and A. Whang. 1993.
Clearance of bacteria injected into the hemolymph of the penaeid shrimp, Sicyonia ingentis.-Journal of Invertebrate Pathology 62: 308-315.

Miosky, D. L., M. Smolowitz, and C. L. Reinisch 1989. Leukemia cell specific protein of the bivalve mollusc Mya arenaria.- Journal of Invertebrate $\mathrm{Pa}$ thology 53: 32-40.

Mori, K., and J. E. Stewart. 1978. Natural and induced bactericidal activity of the hepatopancreas of the American lobster, Homarus americanus.-Journal of Invertebrate Pathology 32: 171-176.

Paterson, W. D., and J. E. Stewart. 1974. In vitro phagocytosis by hemocytes of the American lobster, (Homarus americanus).- Journal of the Fisheries Research Board of Canada 31: 1051-1056.

- - , and B. M. Zwicker. 1976. Phagocytosis as a cellular immune response mechanism in the American lobster, Homarus americanus.-Journal of Invertebrate Pathology 27: 95-104.

Ratcliffe, N. A., A. F. Rowley, S. W. Fitzgerald, and C. P. Rhodes. 1985. Invertebrate immunity: basic concepts and recent advances.-International $\mathrm{Re}$ view of Cytology 97: 183-350.

Smith, V. J., and J. R. S. Chisholm. 1992. Review article: Non-cellular immunity in crustaceans.-Fish \& Shellfish Immunology 2: 1-31.

, and N. A. Ratcliffe. 1978. Host defence reactions of the shore crab, Carcinus maenas (L.), in vitro.- Journal of the Marine Biological Association of the United Kingdom 58: 367-379.

, and $\longrightarrow$. 1980. Host defence reactions of the shore crab, Carcinus maenas (L.): clearance and distribution of injected test particles.- Journal of the Marine Biological Association of the United Kingdom 60: 89-102.

- and K. Söderhäll. 1983. $\beta-1,3$-glucan activation of crustacean hemocytes in vitro and in vivo.-Biological Bulletin 164: 299-314.

- and - 1991. A comparison of phenoloxidase activity in the blood of marine inverte brates.-Developmental and Comparative Immunology 15: 251-261.

Söderhäll, K. 1982. Prophenoloxidase activating system and melanization-a recognition mechanism of arthropods? A review.-Developmental and Comparative Immunology 6: 601-611.

, and L. Hall. 1984. Lipopolysaccharide-induced activation of prophenoloxidase activating system in crayfish hemocyte lysate.-Biochemical and Biophysical Acta 797: 99-104.

- and T. Unestam. 1979. Activation of serum prophenoloxidase in arthropod immunity. The specificity of cell wall glucan activation and activation by purified fungal glycoproteins of crayfish phenoloxidase.-Canadian Journal of Microbiology 25: 406-414.

A. Aspan, and B. Duvic. 1990. The proPO system and associated proteins; role in cellular communication in arthropods.-Research in Immunology 141: 896-907.

, L. Cerenius, and M. W. Johansson. 1994. The prophenoloxidase activating system and its role in invertebrate defence.-Annals of the New York Academy of Sciences 712: 155-161.

Song, Y. L., and Y. T. Hsieh. 1994. Immunostimulation of tiger shrimp (Penaeus monodon) hemocytes for the generation of microbicidal substances-an 
analysis of reactive oxygen species.-Developmental and Comparative Immunology 18: 201-209.

, W. Cheng, C. H. Shen, Y. C. Ou, and H. H. Sung. 1990. Occurrence of Vibrio vulnificus infection for cultured shrimp and eel in Taiwan.-Proceeding of the ROC-JAPAN Symposium on Fish Disease, pp. 172-179.

Stewart, J. E., and B. M. Zwicker. 1972. Natural and induced bactericidal activities of the lobster, Homarus americanus: products of hemocyte-plasma interaction.-Canadian Journal of Microbiology 18: 1499-1509.

Sung, H. H., G. H. Kou, and Y. L. Song. 1994. Vibriosis resistance induced by glucan treatment in tiger shrimp (Penaeus monodon).-Fish Pathology 29: 11-17.

, Y. L. Song, and G. H. Kou. 1991. Potential uses of bacterin to prevent shrimp vibriosis.-Fish \& Shellfish Immunology 1: 311-312.

Unestam, T., and K. Söderhäll. 1977. Soluble fragments from fungal cell walls elicit defence reactions in crayfish.--Nature 267: 45-46.
Wardlaw, A. C., and S. E. Unkles. 1978. Bactericidal activity of coelomic fluid from the sea urchin Echinus esculentus.-Journal of Invertebrate Pathology 32: $25-34$

White, K. N., and N. A. Ratcliffe. 1982. The segregation and elimination of radio- and fluorescent-labelled marine bacteria from the hemolymph of the shore crab, Carcinus maenas.-Journal of the Marine Biological Association of the United Kingdom 62: 819-833.

Yoshida, H., and M. Ashida. 1986. Microbial activation of two serine enzymes and prophenoloxidase in the plasma fraction of hemolymph of the silkworm, Bombyx mori.-Insect Biochmistry 16: 539-545.

RECEIVED: 20 April 1995.

ACCEPTED: 11 September 1995.

Addresses: (HHS, YLY) Department of Microbiology, Soochow University, Taipei, Taiwan, Republic of China; (YLS) Department of Zoology, National Taiwan University, Taipei, Taiwan, Republic of China.

\section{ANNOUNCEMENT}

The following application was published on 20 December 1995 in the Bulletin of Zoological Nomenclature, volume 52, part 4. Comment or advice on this application is invited for publication in the Bulletin and should be sent to the Executive Secretary (I.C.Z.N.), c/o The Natural History Museum, Cromwell Road, London SW7 5BD, United Kingdom.

Case 2952. Paraphronima crassipes Claus, 1879 (Crustacea, Amphipoda): proposed conservation of the specific name. 